\title{
ALTERNATIVE METHODS TO PRESERVE SWEET RED PEPPER PASTE QUALITY: EFFECT OF TEMPERATURE AND PROTECTIVE AGENTS
}

\author{
Ruhan AŞKIN UZEL* \\ Department of Food Processing, Vocational School, Yaşar University, İzmir, Turkey
}

\begin{abstract}
Unlike conventional methods, sweet red pepper paste was produced by various techniques using starter cultures. Products from sweet red pepper paste process were stored at $37^{\circ} \mathrm{C}$ for 60 days. Salinity, acidity, color parameters, invert sugar, brown pigment formation values were determined together with microbiological, statistical and sensory evaluations at different filling temperatures with and without protective agents. Microbiological analysis showed that Escherichia coli (E. coli) was not detected in raw material and in the final product at any production stage, however mold and yeast growth started from beginning of the second storage period. Increase in total sugar content of the final product via protective agent use caused a higher acidity, in other terms a lower $\mathrm{pH}$ value. Sweet red pepper paste treated with protective agents at higher temperature was found to be best with respect to panelists' flavor and color quality scores. The study showed the necessity to use protective agents in sweet red pepper paste production.
\end{abstract}

Keywords: Enthalpy, Sweet red pepper paste, Polyethylene terephthalate (PET), Protective agent

\section{INTRODUCTION}

As a member of the Capsicum family, sweet red pepper is mostly agricultured and consumed in various ways in Chile, Hungary, Turkey, Mediterranean and Middle East countries. Consuming red peppers is believed to be effective for all the following: gas, diarrhea, asthma, toothache, colds, fever, sore throat, hangover, stabilize blood pressure. It is generally used as a spice to medicine, as well as being a natural colorant in many types of foods. Being an alternative, red pepper is highly consumed in home- or factory-made sweet red pepper paste form [1-3]. Total world pepper production is 17,000,000 t [4]. Turkey is the third country after China and Mexico for red pepper production with 1,010,000 $\mathrm{t}$ chili and 390,000 t sweet red pepper productions. Southeast, Mediterranean, Aegean and Marmara regions can be considered as main regions emerging with red pepper production in Turkey $[5,6]$. Today, the pepper yield has reached to a reasonable high level, when compared to the past, with the utilization of high quality seeds and application of agricultural practices adequately. The yield was $570 \mathrm{~kg} / \mathrm{da}$ in $1960 \mathrm{~s}$ which reached to $1400 \mathrm{~kg} / \mathrm{da}$ today [7-9]. The moisture content of raw, red, sweet pepper is approximately $87 \% \pm 0.9 \%$ (wet basis) and it contains totally 46.2 kilocalories, $1.5 \mathrm{~g}$ of proteins, $9.4 \mathrm{~g}$ of total carbohydrates, $0.4 \mathrm{~g}$ of total fats, Vitamin A in $4666 \mathrm{IU}$, Vitamin C in $190 \mathrm{mg}, 10.4 \mathrm{mg}$ of calcium with no cholesterol per 1 cup, chopped (100 g) of sample as details are illustrated in relation to Recommended Dietary Allowance (RDA) (Table 1).

Generally, sweet red pepper paste has been produced traditionally by sun-drying method in Turkey. In case of traditional methods use for sweet red pepper paste production, natural lactic acid fermentation conducted by lactic acid bacteria in natural micro flora is stated to be helpful for the development of flavor and aroma characteristics of the final products [4]. The flavor development occurs during the first two days of concentration when the traditional method is used [2].

Considering the morphological and structural changes during fermentation, browning reactions could be given as a typical example. This reaction may also occur in storage period. Normally, desired sweet 
red pepper paste color is a bright red color. The formation of different pigments can reduce the quality of pepper paste material. Within scope of current study, non-enzymatic way of browning reactions were investigated by means of formation of brown pigments, 5-hydroxymethyl furfural (HMF) and other products as a result of reducing sugars, amino acids, ascorbic acids in the medium [10].

Table 1. Analysis of nutrients for raw, red, sweet pepper per $100 \mathrm{~g}$ [11]

\begin{tabular}{|c|c|c|c|c|c|}
\hline Principle & $\begin{array}{c}\text { Nutrient } \\
\text { Value }\end{array}$ & $\begin{array}{c}\text { Percentage of } \\
\text { RDA }\end{array}$ & Vitamins & $\begin{array}{c}\text { Nutrient } \\
\text { Value }\end{array}$ & $\begin{array}{l}\text { Percentage } \\
\text { of RDA }\end{array}$ \\
\hline Energy & $46.2 \mathrm{kcal}$ & $1.5 \%$ & Folates & $68.5 \mu \mathrm{g}$ & $17 \%$ \\
\hline Carbohydrates & $9.4 \mathrm{~g}$ & $3 \%$ & Niacin & $1.5 \mathrm{mg}$ & $7 \%$ \\
\hline Protein & $1.5 \mathrm{~g}$ & $3 \%$ & Pyridoxine & $0.291 \mathrm{mg}$ & $22 \%$ \\
\hline Total Fat & $0.4 \mathrm{~g}$ & $1 \%$ & Riboflavin & $0.1 \mathrm{mg}$ & $7 \%$ \\
\hline Cholesterol & $0 \mathrm{mg}$ & $0 \%$ & Thiamin & $0.1 \mathrm{mg}$ & $5 \%$ \\
\hline Dietary Fiber & $3.1 \mathrm{~g}$ & $13 \%$ & Vitamin A & $4666 \mathrm{IU}$ & $93 \%$ \\
\hline Moisture & \multicolumn{2}{|c|}{$87 \% \pm 0.9 \%$} & Vitamin C & $190 \mathrm{mg}$ & $317 \%$ \\
\hline \multicolumn{3}{|l|}{ Minerals } & Vitamin E & $2.4 \mathrm{mg}$ & $12 \%$ \\
\hline Calcium & $10.4 \mathrm{mg}$ & $1 \%$ & Vitamin K & $7.3 \mu \mathrm{g}$ & $9 \%$ \\
\hline Copper & $0.017 \mathrm{mg}$ & $1 \%$ & & & \\
\hline Iron & $0.6 \mathrm{mg}$ & $4 \%$ & \multicolumn{3}{|l|}{ Phyto-nutrients } \\
\hline Magnesium & $17.9 \mathrm{mg}$ & $4 \%$ & Carotene- $\beta$ & $1624 \mu \mathrm{g}$ & -- \\
\hline Manganese & $0.2 \mathrm{mg}$ & $8 \%$ & Carotene- $\alpha$ & $20 \mu \mathrm{g}$ & -- \\
\hline Phosphorus & $38.7 \mathrm{mg}$ & $4 \%$ & Cryptoxanthin- $\beta$ & $490 \mu \mathrm{g}$ & -- \\
\hline Zinc & $0.4 \mathrm{mg}$ & $2 \%$ & Lutein-zeaxanthin & $51 \mu \mathrm{g}$ & -- \\
\hline
\end{tabular}

Studies on the quality of sweet red pepper paste have been examined and it was seen that different production methods and process parameters changed some properties of sweet red pepper paste. In one study, effects of different time durations and boiling methods were examined and pulp quality together with pulper yield best resulted at $100{ }^{\circ} \mathrm{C}$ boiling temperature for $8 \mathrm{~min}$. of boiling time in terms of efficiency $[2,12]$. In another study, the effect of pungent flavor component called capsaicin was investigated by means of distortion causing microorganisms and it was finally observed that all bitterness components were effective in overlapping these types of microorganisms [13-16]. In case of effects of production techniques on process parameters, traditionally produced sweet red pepper paste from red peppers having $\mathrm{pH}$ value of 5.20 and acidity of 0.26 (as means of citric acid) did not change the process parameters (acidity, pigment formation, viscosity, etc.) during storage period. But in any other method assisted with vacuum evaporation, same values were observed to be increased [3, 12].

The number of literature samples for sweet red pepper paste production could be increased. However, there have been very few studies regarding such parameters for sweet red pepper paste production quality. But it is difficult to find samples for red sweet pepper paste production parameters. This research, therefore, is a unique study in which all production methods have been investigated in combination with quality parameters for sweet red pepper paste production in the presence and absence of protective agents at different filling temperatures. So, following production steps, three pulp samples were taken for each sample and $\mathrm{pH}$, salinity, acidity, Hunter color parameters, invert sugar, brown pigment formation values were determined together with microbiological evaluations such as aerobic plate count (APC), and mold and yeast counts, lactic acid bacteria count, E.coli counts using appropriate techniques during the storage period.

\section{EXPERIMENTAL}

\subsection{Materials}

In current study, raw materials of sweet red peppers grown in four separate batches in various locations of the Aegean Region (Turkey) were investigated and have been supplied by local manufacturers. The red sweet peppers, which have approximately $87 \%$ moisture content (on wet basis), were flat, conical 
shaped, thick fleshy and less seedy. The size per sweet red pepper raw material supplied was at 15-18 $\mathrm{cm}$ range and the weight per sweet red pepper was about 150-200 grams while each sweet red pepper has about 2,5 - 4,5 cm diameter. Prior to application of different process parameters, randomly selected parts from sample material were collected for color determination and initial micro flora detection. Sodium benzoate, potassium sorbate, phenolphthalein and sodium chloride were obtained from Merck (Darmstadt, Germany).

\subsection{Sweet Red Pepper Paste Production}

Ensuring the day of harvest of the sweet red peppers, sweet red pepper paste production was done in the same day with raw material supply. Seed and stems of peppers were initially separated and washed thoroughly with three times the weight of mass of water. After mincing in a shredder to a size about 80 $\mathrm{mm}$ (Nanyang Wanxin Food Machinery Co., Ltd, China), whole material was steamed at $110 \pm 1{ }^{\circ} \mathrm{C}$ for 5,8 , and 11 minutes and boiled for 25 minutes in water until they are tendered. The water used for boiling in production was determined to be approximately three times the amount of pepper. Boiled peppers were palpated and pulp was obtained. Following evaporation, sweet red pepper paste samples were moved to filling tanks and then were ready for consumption after sterilization and cooling processes following relevant production steps (Figure 1).

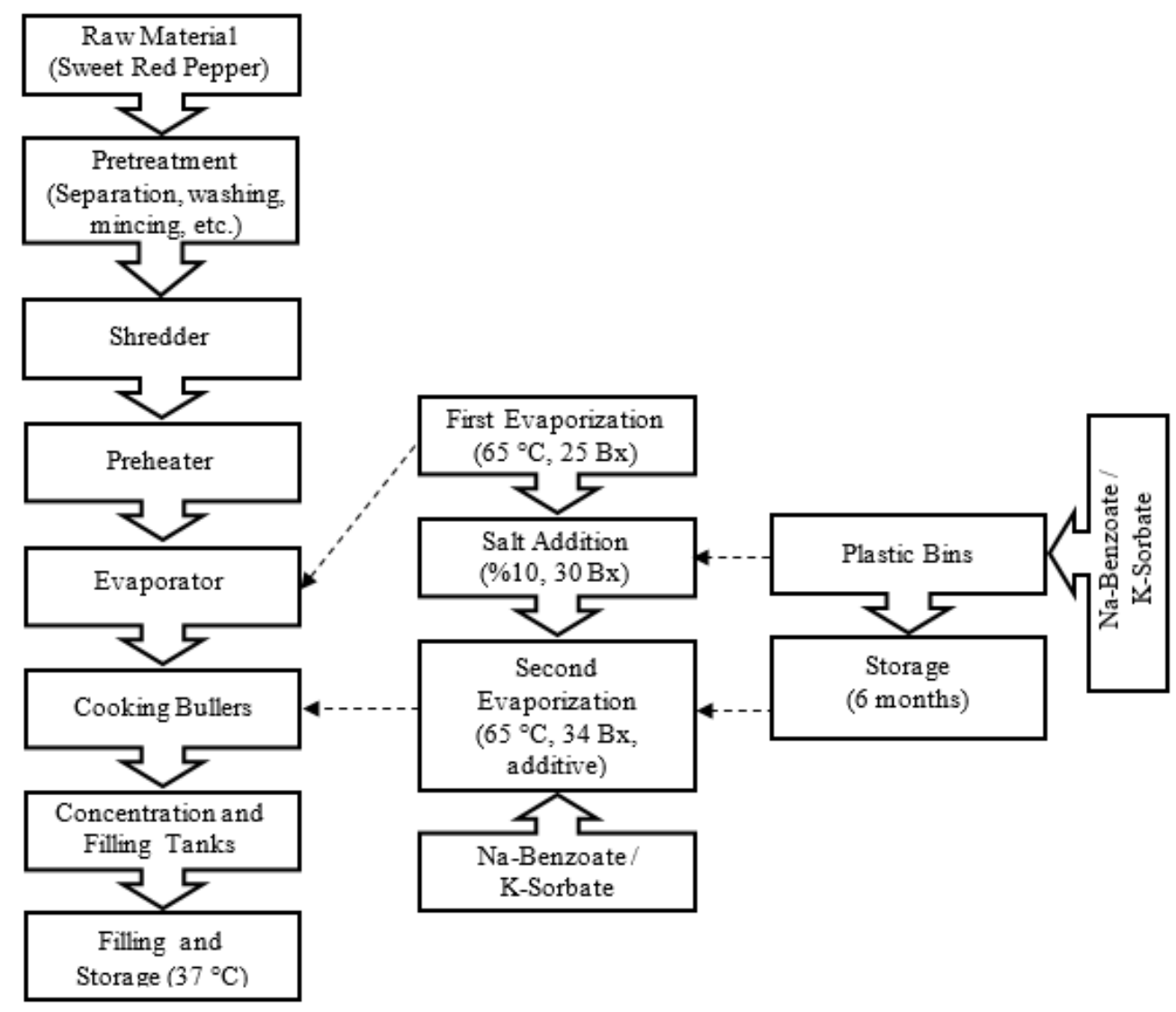

Figure 1. Sweet red pepper paste production steps

In Figure 1, the dashed lines express the process steps between the main production steps starting from raw material through the last step of filling and storage. Final product which is in pulp form was taken into two separate batches. The mixture of $0.2 \%$ concentrated protective agent (equal proportions of NaBenzoate and K-Sorbate) which was prepared in the framework of the limits given by the Turkish 
Standards Institute was added with dosing pumps while no preventative was added to the other pulp in the second tank (Figure 2). In the process with protective agent addition, Na-Benzoate / K-Sorbate mix was fed from salt addition and second evaporation steps.

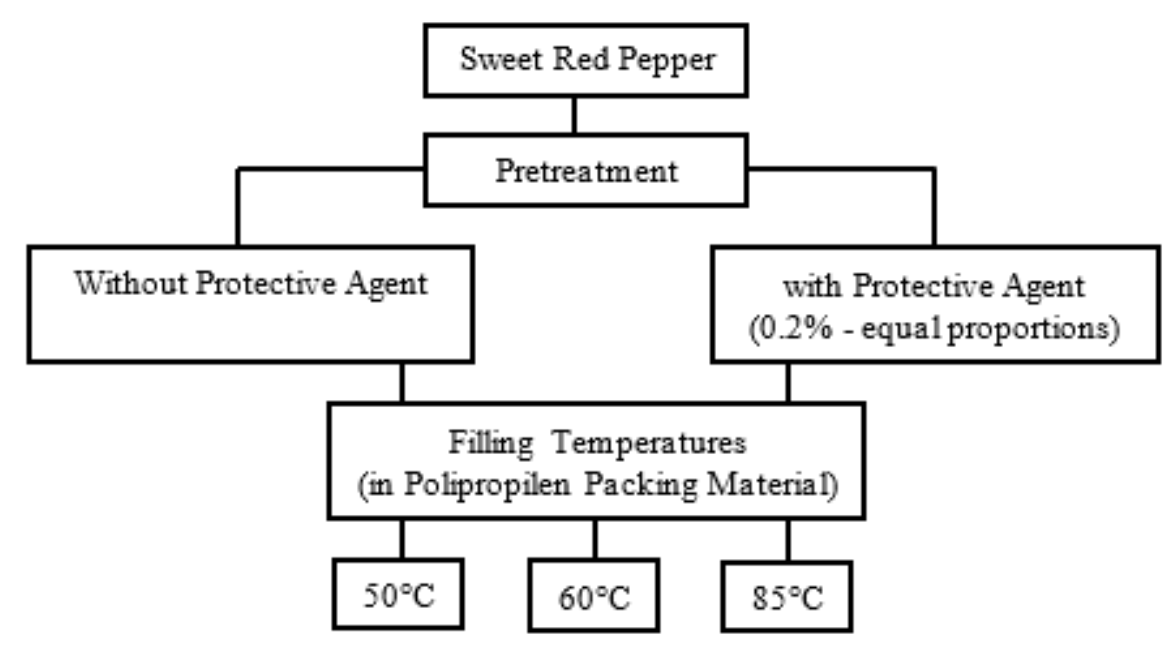

Figure 2. Process conditions for sweet red pepper paste production

The same procedure (heating, cooling, evaporation, etc.) was applied to both pulps in the tanks and filling process took place at three different temperatures of 50,60 and $85^{\circ} \mathrm{C}$, respectively. The selected temperatures indicated in Figure 2 have been determined as the best conditions representing each process parameter at the end of several serial tests. PET (Polyethylene Terephthalate) was used as a packaging material. Sweet red pepper pastes were stored in an incubator (Binder Redline, RI 53, Turkey) at $37^{\circ} \mathrm{C}$ for 60 days in air-tight containers.

\subsection{Chemical Analysis}

Samples were analyzed for determination of acidity, $\mathrm{pH}$, salinity, color determination, brown pigment formation and invert sugar values. Most of analytical features of sweet red pepper paste were determined by AOAC (1990 and 1995) methods and TSI regulations. For analyses expressed above, about $100 \mathrm{~g}$ of samples were taken and homogenized using a blender (Hamilton Beach 2-Speed Blender with 1/2 Gallon Stainless Steel Container).

As determined by the Turkish Standards Institute (TSI), the value of total acidity for sweet red pepper paste is expressed as citric acid (Anonymous, 1995). Sweet red pepper paste sample was taken and 20 $\mathrm{g}$ of water was added to $50 \mathrm{~g}$ of homogenized sample. Titration was done using $0.1 \mathrm{~N}$ of $\mathrm{NaOH}$ with two or three drops of $1 \%$ of phenolphthalein.

The $\mathrm{pH}$ is generally used to determine processing requirements and the applicability of GMP regulations for regulatory purposes. Methodology for $\mathrm{pH}$ is generally available from $\mathrm{pH}$ meter and electrode manufacturers. As an assisting value, approximate range of $\mathrm{pH}$ level for sweet red pepper paste is expressed as $3.5-4.7$ [17]. First of all, $10 \mathrm{~g}$ of sample was homogenized using distilled water in 1/ 10 sample/water ratio as described by AOAC (1990). $\mathrm{pH}$ was measured by digital $\mathrm{pH}$ meter (H. L. Scientific Industries, Haryana, India) and the readings were corrected at $20^{\circ} \mathrm{C}$.

The salinity was measured using a digital salinity meter (SALINTEST Salt Content Meter, HI98203, Hanna Instruments, Istanbul, Turkey). Approximately $2.5 \mathrm{~g}$ of the pulped sample was meshed homogenously and around $25 \mathrm{~mL}$ of distilled water was added. Slurry was then again mixed and salinity was recorded. 
The Brix of the samples was measured before and after each application with a refractometer (KYOTO RA 600, Kutay Laboratuvar Cihazları A.Ş., İzmir, Turkey). The samples were stored at room temperature for 3 months during the experiments and for additional 6 months for the proof tests.

The development of brown pigment was measured in terms of optical density at absorbance at $420 \mathrm{~nm}$ on a Beckman DB-G spectrophotometer (Beckman Instruments Inc., USA). Proper dilution of $20 \mathrm{~g}$ of sample with distilled water (about $1 / 350 \mathrm{~g}$ sweet red pepper paste/g water) was used during the test [18, 19]. Invert sugar in the products was determined as invert sugar and reducing sugar content was detected using specified Lane-Eynon general volumetric method [20]. Before invert sugar measurement, sample bottle was shaken to assure that its contents were well mixed. Analyses were performed on at least two parallel samples and distilled water or water of equivalent purity were used for preparation of the reagents.

\subsection{Microbiological Counts}

A $30 \mathrm{~g}$ of sample was taken from each sample and homogenized in a sterile Waring 8011 EB Blender (Altan Endustriyel ve Laboratuvar Cih. A.Ş., Turkey) containing $270 \mathrm{ml} 0.1 \%$ peptone water. Samples were diluted serially using $0.1 \%$ peptone (Sigma-Aldrich Chemie GmbH, Taufkirchen, Germany). Standard plate count method was used for determination of E. coli as an indirect measurement of cell density. The sample material was diluted with sterile phosphate buffer diluent until the bacteria were dilute enough to count accurately. The initial dilution is made by transferring $1 \mathrm{ml}$ of $E$. coli sample to a sterile saline blank. The dilution was then shaken by grasping the tube between the palms of both hands and rotating quickly to create a vortex and was diluted for one more time. After series of dilution, the agar which was inserted in the agar pour tube at $50^{\circ} \mathrm{C}$ water bath was removed and poured into the plates. Following the sample addition and incubation at $37^{\circ} \mathrm{C}$ for 24 hours, petri plates containing between 30 and 300 colonies were selected and were counted. Lactic acid bacteria count together with mould-yeast count were done using Aerobic Plate Count (APC) method using Aerobic Plate Count Agar (PCA) (Sigma-Aldrich, Germany) and Potato Dextrose Agar (PDA) (Sigma-Aldrich, Germany), respectively. Incubation temperature and time were $35-37{ }^{\circ} \mathrm{C}$ for $24-48$ hours and $25-28{ }^{\circ} \mathrm{C}$ for 5 days in case of aerobic plate count and mould-yeast count, respectively.

\subsection{Statistical Analysis}

Data on the protective agent addition effect against filling temperature difference on sweet red pepper paste quality were analyzed with Duncan's multiple comparison test $(p<0.05)$ using the SPSS software package, version 13.0 (SPSS Inc., Chicago, IL, USA) [21]. The statistical analyses were conducted using SPSS software (SPSS Inc., version 11.0) by analysis of variance (ANOVA) to establish effects of protective agent addition and different filling temperatures the differences in the treatments and 95\% confidence level was taken into consideration. In addition, for formation production patterns "Design Expert Ver. 7.0.0" program was used [22]. This program revealed a scientific manner about mixing orders of each protective agent, mixing proportions and the number of parallel productions.

\subsection{Sensory Analysis}

Sweet red pepper paste samples were evaluated by considering aroma, texture and color sensory properties. For the analysis, a 5 people ( 3 women and 2 men) have been assigned from all trained panelists. Quality attributes were rated using the numerical scale for the above-mentioned properties and quality characteristics of the measured intensity. A test card was formed including quality characteristics below:

\footnotetext{
- $\quad$ Appearance properties

- Textural features

- Odor characteristics

- Taste features
} 
Samples were given to panelists one by one, preferably and a scale beginning from 1 to 10 was used for each sensory attribution with respect to panelists' perceptions. The results obtained from panelists were evaluated by variance analysis.

\section{RESULTS AND DISCUSSION}

Raw material was processed by applying basic production steps for the sweet red pepper paste production and the steps were followed by temperature, pressure, humidity measurements assisted with energy efficiency tests (Figure 1). Sampling was done for every 15-day intervals during storage period and final product was generally examined as details were explained below.

\subsection{Microbiological Assessment}

Microbiological analysis showed that $E$. coli was not detected in raw material and the final product at any production stage (Table 2). However, mold and yeast development were seen to begin after the first month of storage period. When the academic studies examining the storage conditions of red pepper sala were also examined, the findings obtained indicate that the microbial measurements made with similar methods overlap each other [23, 24].

Table 2. Changes in microbial counts during storage in the sweet red pepper paste prepared by different methods $(\mathrm{cfu} / \mathrm{g})^{*}$

\begin{tabular}{|c|c|c|c|c|c|c|c|c|c|}
\hline \multirow{2}{*}{$\begin{array}{l}\text { Time } \\
\text { (days) }\end{array}$} & \multirow{2}{*}{$\begin{array}{l}\text { Temp } \\
\left({ }^{\circ} \mathrm{C}\right)\end{array}$} & \multicolumn{3}{|c|}{ Aerobic Plate Count (APC) } & \multirow{2}{*}{$\begin{array}{c}\begin{array}{c}\text { Mould- } \\
\text { Yeast } \\
\text { Count }\end{array} \\
\text { With P.A. }\end{array}$} & \multicolumn{2}{|c|}{$\begin{array}{c}\text { Lactic Acid Bacteria } \\
\text { Count }\end{array}$} & \multicolumn{2}{|c|}{ E. Coli Count } \\
\hline & & $\begin{array}{l}\text { Without } \\
\text { P.A.** }\end{array}$ & With P.A. & $\begin{array}{l}\text { Without } \\
\text { P.A. }\end{array}$ & & $\begin{array}{l}\text { Without } \\
\text { P.A. }\end{array}$ & With P.A. & $\begin{array}{l}\text { Without } \\
\text { P.A. }\end{array}$ & With P.A. \\
\hline \multirow{2}{*}{$\begin{array}{l}\text { Raw } \\
\text { Material }\end{array}$} & 50 & $3 \times 10^{4}$ & $5 \times 10^{5}$ & $2 \times 10^{3}$ & $2 \times 10^{3}$ & $2 \times 10^{4}$ & $1 \times 10^{4}$ & 0 & 0 \\
\hline & 60 & $3 \times 10^{4}$ & $5 \times 10^{5}$ & $2 \times 10^{3}$ & $2 \times 10^{3}$ & $2 \times 10^{4}$ & $1 \times 10^{4}$ & 0 & 0 \\
\hline \multirow{2}{*}{0} & 50 & 0 & 0 & 0 & 0 & 0 & 0 & 0 & 0 \\
\hline & 60 & 0 & 0 & 0 & 0 & 0 & 0 & 0 & 0 \\
\hline \multirow{2}{*}{15} & 50 & 39.00 & 0 & 0 & 0 & 0 & 0 & 0 & 0 \\
\hline & 60 & 12.33 & 0 & 0 & 0 & 0 & 0 & 0 & 0 \\
\hline \multirow{2}{*}{30} & 50 & 47.83 & 0 & 0 & 0 & 0 & 0 & 0 & 0 \\
\hline & 60 & 18.50 & 0 & 0 & 0 & 0 & 0 & 0 & 0 \\
\hline \multirow{2}{*}{45} & 50 & 64.16 & 0 & 57.16 & 0 & 0 & 0 & 0 & 0 \\
\hline & 60 & 33.66 & 0 & 34.16 & 0 & 0 & 0 & 0 & 0 \\
\hline \multirow{2}{*}{60} & 50 & 82.33 & 0 & 106.00 & 0 & 0 & 0 & 0 & 0 \\
\hline & 60 & 46.66 & 0 & 77.33 & 0 & 0 & 0 & 0 & 0 \\
\hline
\end{tabular}

** cfu/g: colony forming unit per grams of sample

* P. A.: $0.2 \%$ concentrated protective agent (equal proportions of Na-Benzoate and K-Sorbate)

The raw material of a total aerobic plate count (APC) together with mold and yeast count from $2 \times 10^{3}$ to $5 \times 10^{5}$ varied after production and during storage period. At this stage, storage time was not stopped and samples for analysis were collected for each 15-day periods. There was not any microbiological development in any of the samples with protective agents. Traditionally produced sweet red pepper paste had a higher $(\mathrm{P}<0.05)$ APC number than the other protective agent added samples. This could be due to the contamination of microorganisms from air during the concentration of sweet red pepper paste as a result of not using protective techniques.

Although the number of total bacteria count was decreased as a result of temperature increase in the samples without protective agent, some growth has observed 15 days after the first analysis. It was remarkable that this situation continued increasingly during storage period. Samples without protective agents followed a similar trend of mold and yeast growth, but the number started to increase after 30 days of storage. ANOVA indicated that protective agent addition reduced $(\mathrm{P}<0.05)$ APC in the sweet 
red pepper pastes. For all samples at same storage conditions on the temperature and the duration basis, the APC was decreased to zero in protective agent use (Table 2). Despite the lactic acid bacteria content of raw material, there was not any growth after production and during storage. In addition, microbial growth rate was higher in samples with thermal process at low temperatures. Because total bacteria count and mold-yeast count followed an increased growing rate for samples without protective agent, the necessity of protective agent usage was approved.

Statistical analysis indicated that all the two-way interactions (time $\times$ temperature, time $\times$ protective agent, and protective agent $\times$ temperature) were significant $(\mathrm{P}<0.05)$. This means that effect of combinations of the factors changed the total microbial count more than the effect of one factor. In other words, combinations of effects of production addition of protection agents with temperature treatment could be used for decreasing the total microbial count of sweet red pepper pastes.

\subsection{Chemical Changes}

Due to the inherent differences in raw materials used for the production of sweet red pepper paste, $\mathrm{pH}$ values were changed in the range of 4.38 - 4.42. Temperature difference in filling process did not change the $\mathrm{pH}$ value, whereas increase in total sugar content of the final product caused a higher acidity, in other terms a lower $\mathrm{pH}$ value. However, it was noteworthy that samples with protective agents were higher than the samples without protective agents in case of increase in acidity. In other words, use of protective agents increased sweet red pepper paste acidity (Table 3).

Table 3. Changes in $\mathrm{pH}$ values, acidity, invert sugar and brown pigment formation during storage in sweet red pepper paste prepared by different methods

\begin{tabular}{|c|c|c|c|c|c|c|c|c|c|}
\hline \multirow{2}{*}{$\begin{array}{l}\text { Time } \\
\text { (days) }\end{array}$} & \multirow{2}{*}{$\begin{array}{l}\text { Temp. } \\
\left({ }^{\circ} \mathrm{C}\right)\end{array}$} & \multicolumn{2}{|c|}{ pH values } & \multicolumn{2}{|c|}{ Total Acidity (\%) } & \multicolumn{2}{|c|}{ Invert Sugar (\%) } & \multicolumn{2}{|c|}{$\begin{array}{c}\text { Brown Pigment } \\
\text { (number/grams) }\end{array}$} \\
\hline & & $\begin{array}{l}\text { Without } \\
\text { P.A.* }\end{array}$ & With P.A. & $\begin{array}{l}\text { Without } \\
\text { P.A. }\end{array}$ & With P.A. & $\begin{array}{l}\text { Without } \\
\text { P.A. }\end{array}$ & With P.A. & $\begin{array}{l}\text { Without } \\
\text { P.A. }\end{array}$ & With P.A. \\
\hline \multirow{2}{*}{$\begin{array}{l}\text { Raw } \\
\text { Material }\end{array}$} & 50 & 4.42 & 4.38 & 0.25 & 0.36 & 3.00 & 2.50 & 2 & 2 \\
\hline & 60 & 4.42 & 4.38 & 0.25 & 0.36 & 3.00 & 2.50 & 2 & 2 \\
\hline \multirow{2}{*}{0} & 50 & 4.42 & 4.33 & 0.65 & 0.95 & 15.96 & 14.13 & 1 & 1 \\
\hline & 60 & 4.43 & 4.33 & 0.66 & 0.96 & 16.01 & 14.17 & 2 & 2 \\
\hline \multirow{2}{*}{15} & 50 & 4.35 & 4.30 & 0.67 & 0.98 & 16.00 & 14.05 & 1 & 2 \\
\hline & 60 & 4.42 & 4.31 & 0.68 & 0.96 & 16.05 & 14.13 & 1 & 1 \\
\hline \multirow{2}{*}{30} & 50 & 4.36 & 4.33 & 0.69 & 0.98 & 15.98 & 14.02 & 1 & 1 \\
\hline & 60 & 4.37 & 4.31 & 0.69 & 0.95 & 16.00 & 14.08 & 2 & 1 \\
\hline \multirow{2}{*}{45} & 50 & 4.41 & 4.31 & 0.68 & 0.96 & 15.93 & 14.05 & 2 & 2 \\
\hline & 60 & 4.44 & 4.32 & 0.68 & 0.97 & 16.05 & 14.12 & 2 & 1 \\
\hline \multirow{2}{*}{60} & 50 & 4.35 & 4.32 & 0.68 & 0.97 & 16.05 & 14.08 & 2 & 1 \\
\hline & 60 & 4.41 & 4.31 & 0.69 & 0.98 & 16.07 & 14.17 & 2 & 1 \\
\hline
\end{tabular}

* P. A.: $0.2 \%$ concentrated protective agent (equal proportions of Na-Benzoate and K-Sorbate)

Total acidity and $\mathrm{pH}$ values followed a same path of parallel changes (Table 3). The amount of invert sugar in the sweet pepper was changed from $3.0 \%$ to $2.5 \%$. This difference has been due to processing variety of raw materials. Because the structure of the material was much more conserved in case of less availability of decomposable invert sugars. Invert sugar value was rather increased at higher temperatures as a result of concentration and decomposition of sucrose to glucose and fructose by the effect of thermal processes (Table 3) [25].

Looking at the brown pigment formation level on all samples, there was no difference between raw material and processed samples. This proves that there was no perforation on palper sieves during production and the thermal process did not affect the formation of brown pigments (Table 3). These results were in relation to other studies in the literature having defended that the higher number of brown pigment formation was closely related with an increase in $\mathrm{pH}$ level [26, 27]. 


\subsection{Physical and Sensory Quality}

Sweet red pepper paste treated with protective agents at higher temperature was found to be best with respect to panelists' flavor and color quality scores. This could be due to acid taste caused by increase in total sugar content of the final product. Total sugar increase was a result of concentration and decomposition of sucrose to glucose and fructose by the effect of thermal processes [25]. However, flavor scores of sweet red pepper paste produced without protective agents were not good because of low acid taste and of color unacceptability. During production of pastes without protective agents, the color became darker as a consequence of the brown pigment formation at $60^{\circ} \mathrm{C}$ filling temperature from the 30th day of storage period and resulted in low acceptability of color scores by panelists. Color was also evaluated using sensory analysis depending on the scoring method (100 point method). Mainly three parameters of intensity, uniformity, homogeneity were investigated and it was seen that the responses of panelists gave better reflections for the samples with protective agents rather than the ones without protective agents. Researchers have shown that the use of protective agents such as sodium benzoate or potassium sorbate improves both the quality and the sensory properties of sweet red pepper paste $[28,29]$. However, panelist's reaction changed when the labels of samples containing protective agents were changed with the ones without protective agents, so that they approached to the samples with prejudice against the use of preservatives in foods, even though they are allowed at the limits [30].

\section{CONCLUSION}

Various production methods were investigated in combination with quality parameters for sweet red pepper paste production in the presence and absence of protective agents at different filling temperatures. Microbial, chemical, and physical and sensory qualities of sweet red pepper paste were examined in sweet red pepper paste produced by various production techniques at different filling temperatures with and without protective agents. Results showed that effect of combinations of the factors changed the total microbial count more than the effect of one factor. Temperature difference in filling process did not change the $\mathrm{pH}$ value, whereas increase in total sugar content of the final product caused a higher acidity, in other terms a lower $\mathrm{pH}$ value. During production of sweet red pepper paste without protective agents, the color became darker as a consequence of the brown pigment formation and resulted in low acceptability of color scores by panelists. Effects of filling temperature and storage of the paste included all analyzes, sensory characteristics and physical properties.

\section{REFERENCES}

[1] Sook A, Myoung-Sool D, Su-Ok K, Hun-Soon J, Young-In K, Hye-Jung K, Kun-Young P. Antiobesity Effect of Kochujang (Korean Fermented Red Pepper Paste) Extract in 3T3-L1 Adipocytes. Journal of Medicinal Food 2006; 9(1): 15-21.

[2] Young KD, Kyung RC, Hye-Jeong Y, Dai-Ja J. Gochujang (Korean red pepper paste): A Korean ethnic sauce, its role and history. Journal of Ethnic Foods 2015; 2(1): 29-35.

[3] Bozkurt H, Erkmen OJ. Effect of salt, starter culture and production techniques on the quality of hot pepper paste. Food Eng 2005; 69: 473-479.

[4] Semenli T, Mavi K. Determining the yield and several quality parameters of 'Chili Jalapeno' in comparison to 'Pical' and 'Geyik Boynuzu' pepper cultivars under Mediterranean conditions. Afr. J. Agric. Res 2010; 5(20): 2825-2828.

[5] Sezena SM, Yazar A, Daşgan Y, Yucel S, Akyıldız A, Tekin S, Akhoundnejad Y. Evaluation of crop water stress index (CWSI) for red pepper with drip and furrow irrigation under varying irrigation regimes. Agricultural Water Management 2014; 143: 59-70. 
Aşkın Uzel / Anadolu Univ. J. of Sci. and Technology A-Appl. Sci. and Eng. 18 (3) - 2017

[6] Tosun A, Özden S. Ochratoxin A in red pepper flakes commercialised in Turkey. Food Additives \& Contaminants: Part B Surveillance 2016; 9(1): 44-50.

[7] Duman AD, Zorlugenç B, Evliya B. Kahramanmaraş'ta Kırmızı Biberin Önemi ve Sorunları. KSÜ Fen ve Mühendislik Dergisi 2002; 5(1): 111-113.

[8] Erkmen O. Basic Methods for the Microbiological Analysis of Foods. 2nd ed. New York, USA: Nobel Publishing Company, 2010.

[9] Gül A, Özel R, Işik HJ. Adana ili merkezinde tüketicilerin biber salçası tüketimini etkileyen faktörler. Harran University Agr. Fac 2005; 9(4): 23-31.

[10] Calligaris S, Mastrocola D, Nicoli Mc, Lerici CR. Review of non-enzymatic browning and antioxidant capacity in processed food. Trends Food Sci Tech 2001; 11(9): 340-346.

[11] USDA National Nutrient Database for Standard Reference (Release 28, released September 2015, slightly revised May 2016)

[12] Won-Il C, Eun-Jung K, Hee-Jeong H, Yun-Hwan C, Hee SC, Jun-Bong C, Myong-Soo C. Continuous ohmic heating system for the pasteurization of fermented red pepper paste. Innovative Food Science \& Emerging Technologies 2017; 42: 190-196.

[13] Liu TT, Yi CH, Lei WY, Hung XS, Chen CL. Influence of repeated infusion of capsaicin-contained red pepper sauce on esophageal secondary peristalsis in humans. Neurogastroenterol. Motil 2014; 26: $1487-1493$.

[14] Lim J. Effect of packaging unit and temperature on the volume expansion of flexible permeable package of kimchi. Packag Tech Sci 2001; 14: 41-48.

[15] Lim HJ, Kim GD, Jung EY, Seo, HW, Joo ST, Jin SK, Yang HS. Effect of Curing Time on the Physicochemical and Sensory Properties of Beef Jerky Replaced Salt with Soy Sauce, Red Pepper Paste and Soybean Paste. Asian-Australas J Anim Sci 2014; 27(8): 1174-1180.

[16] Young-Eun S, Hwa-Sook B, Dong-Han K. Effect of the Addition of Antimicrobial Materials Before and After Aging on the Physicochemical Properties of Low-Salt Kochujang during Storage. Journal of Applied Biological Chemistry 2014; 57(4): 287-294.

[17] Warren LL. Examination of canned foods. In FDA Bacteriological Analytical Manual. 8th ed. Gaithersburg, Maryland, USA: AOAC International, 1998.

[18] Stamp CA, Labuza TP. Kinetics of the Maillard Reaction between Aspartame and Glucose in Solution at High Temperatures. J Food Sci 2006; 48(2): 543-544.

[19] Yurdagel Ü, Aktan N, Ural AJ. Kırmızı biberin konserveye işlenmesi sırasında askorbik asit ve betakaroten niceliğindeki degişmeler üzerine bir çalışma. Ege Unv. Agr. Fac 1978; 15(2): 231-241.

[20] AOAC. Official Methods of Analysis. 16th ed. Washington, D.C, USA: Association of Official Analytical Chemists, 1995.

[21] SPSS. SPSS for Windows. Version 11.0.1. Chicago, USA: SPSS Inc., 2010. 
Aşkın Uzel / Anadolu Univ. J. of Sci. and Technology A-Appl. Sci. and Eng. 18 (3)- 2017

[22] STAT-EASE. Stat-Ease Design Expert Package. Version 7.0.0. Minneapolis, MN: Productivity Press, 2005.

[23] Duman AD. Storage of red chili pepper under hermetically sealed or vacuum conditions for preservation of its quality and prevention of mycotoxin occurrence. Journal of Stored Products Research 2010; 46(3): 155-160.

[24] Sook Jong R, Jang-Eun L, Cherl-Ho L. Importance of lactic acid bacteria in Asian fermented foods. Microbial Cell Factories 2011 10(Suppl 1): 5-11.

[25] Purchase BS, Day-lewis M and Schaffler KJ. A comparative study of sucrose degradation in different evaporators. Proceedings of the South African Sugar Technologists' Association 1987; 813.

[26] Kazumasa W, Ayano N, Watanabe M, Kenta N, Shosuke I. Pheomelanogenesis is promoted at a weakly acidic pH. Pigment Cell Melanoma Res. 2017; 30: 372-377.

[27] Daniela T, Sara CR, Paul AC, The influence of $\mathrm{pH}$ on pigment formation by lignicolous fungi. International Biodeterioration \& Biodegradation 2013; 80: 22-28.

[28] Russell SJK, Paul ASB. An overview of binary taste-taste interactions. Food Quality and Preference 2003; 14(2): 111-124.

[29] Marcelino K, Ana P, Isabel D, Carlos M, Duarte P. Assessment of Benzoic Acid, and Benzene in "Pimenta-Da-Terra" Red Hot Pepper (Capsiccum Sp) Processed Traditionally. Journal of Nutrition and Food Science 2013; 3: 6-10.

[30] John Krebs. Food: A Very Short Introduction. Oxford University Press, UK, 2013. 